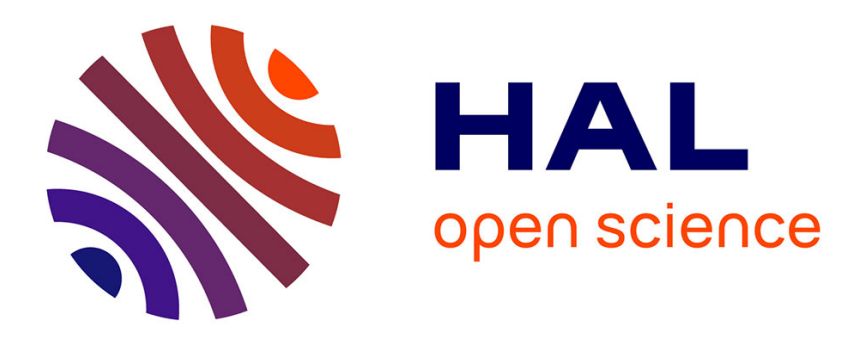

\title{
A Method of determination of dynamic influence of the forest on the boundary layer, using two Doppler sodars
}

\author{
Christine Mazaudier, Alain Weill
}

\section{To cite this version:}

Christine Mazaudier, Alain Weill. A Method of determination of dynamic influence of the forest on the boundary layer, using two Doppler sodars. Journal of Applied Meteorology, 1989, 28 (8), pp.1-6. hal-01009293

\section{HAL Id: hal-01009293 \\ https://hal.science/hal-01009293}

Submitted on 17 Jun 2014

HAL is a multi-disciplinary open access archive for the deposit and dissemination of scientific research documents, whether they are published or not. The documents may come from teaching and research institutions in France or abroad, or from public or private research centers.
L'archive ouverte pluridisciplinaire HAL, est destinée au dépôt et à la diffusion de documents scientifiques de niveau recherche, publiés ou non, émanant des établissements d'enseignement et de recherche français ou étrangers, des laboratoires publics ou privés. 


\title{
A Method of Determination of Dynamic Influence of the Forest on the Boundary Layer Using Two Doppler Sodars
}

\author{
CHRISTINE MAZAUDIER \\ CNET/CRPE, Saint-Maur des Fossés, France \\ ALAIN WEILL \\ CNET/CRPE, Issy les Moulineaux, France
}

(Manuscript received 30 March 1988, in final form 8 October 1988)

ABSTRACT

\begin{abstract}
Doppler sodar soundings of wind velocities were routinely performed during the intensive phase of the HAPEXMOBILHY experiment over two different canopies: forested and bare ground. The purpose of the experiment was to observe the turbulent frictional effect induced by the forest canopy. Different effects were observed: 1) the frictional forest effect depends on the magnitude and direction of the wind system; and 2) the wind speed reduction over the forest is observed up to heights equal to or greater than $65 \mathrm{~m}$. In the layer from the top of the trees $(19 \mathrm{~m})$ up to $50 \mathrm{~m}$ the speed is reduced by $30 \%-60 \%$. Above $50 \mathrm{~m}$, the wind speed is reduced by $10 \%-$ $15 \%$. These observations are consistent with an estimated forest surface layer thickness of $30 \mathrm{~m}$. Finally this paper proposes a method to derive the differential "forested/unforested" turbulent friction from data.
\end{abstract}

\section{Introduction}

During the intensive observational phase of the HAPEX-MOBILHY campaign (André et al. 1988), the vertical profile of mean horizontal wind in the surface and boundary layers over two different canopies (forested and bare ground) were observed with a system of two monostatic Doppler sodars (with three antennas) and a minisodar. The main goal of this sodar experiment was to study the effect of the forest on the atmospheric flow through sensible heat fluxes and momentum fluxes.

This paper, focuses on the momentum flux indicated by the wind profiles and gives preliminary results demonstrating the feasibility of the measurement.

In the first section we briefly describe the sodar experiment and the collected data set. Then, in the second section, we present selected cases in order to quantify the forest dynamical effect. In a third section, a method to derive the differential "forested/unforested" turbulent frictional force from the sodar data is proposed. The last section includes comments on these results.

This is the first time that sodars have been used to study the forest boundary layer. In the past, different techniques have been used to determine sensible heat

Corresponding author address: Ms. Christine Mazaudier, CRPE/ CNET/CNRS, 4, Avenue de Neptune, 94107 Saint-Maur-Des-Fosses, Cedex, France. and momentum fluxes above the forest (Dyer and Maher 1965; Dyer et al. 1967; Hicks 1969; Hicks et al. 1975; Thom et al. 1975; Shuttleworth et al. 1984). In all of these studies, the fluxes were derived from observations of temperature and wind fluctuations made by thermometers and anemometers (sonic, gill propeller anemometer) at few levels just above the canopy. Sodar measurements provide profile of wind speed measurements from several meters above the canopy up to 500 meters. The method, which was used to calculate the differences in momentum flux between forested/unforested wind profiles, was derived from a method proposed by Clarke (1970).

\section{Sodar experiment and data set}

The intensive observational phase of the HAPEXMOBILHY experiment took place in the southwest of France from the beginning of May to the middle July of 1986. A complete description of this experiment has been given by André et al. (1988).

The sodar experiment was operating from 22 May 1986 to 30 June 1986. Two sodars (A and B) were used routinely at Estampon, a forested site $\left(44^{\circ} 04^{\prime} 45^{\prime \prime} \mathrm{N}, 00^{\circ} 04^{\prime} 20^{\prime \prime} \mathrm{W}\right)$, and at Lubbon, a large unforested area $\left(1800 \mathrm{~m} \times 1800 \mathrm{~m}, 44^{\circ} 07^{\prime} \mathrm{N}\right.$, $00^{\circ} 03^{\prime} \mathrm{W}$ ), $4 \mathrm{~km}$ from Estampon (Fig. 1). Figure 1 displays the extent of the forest area (bottom panel), and the topography of the clearings (top panel). The forest is composed of pine trees averaging $19 \mathrm{~m}$ in 

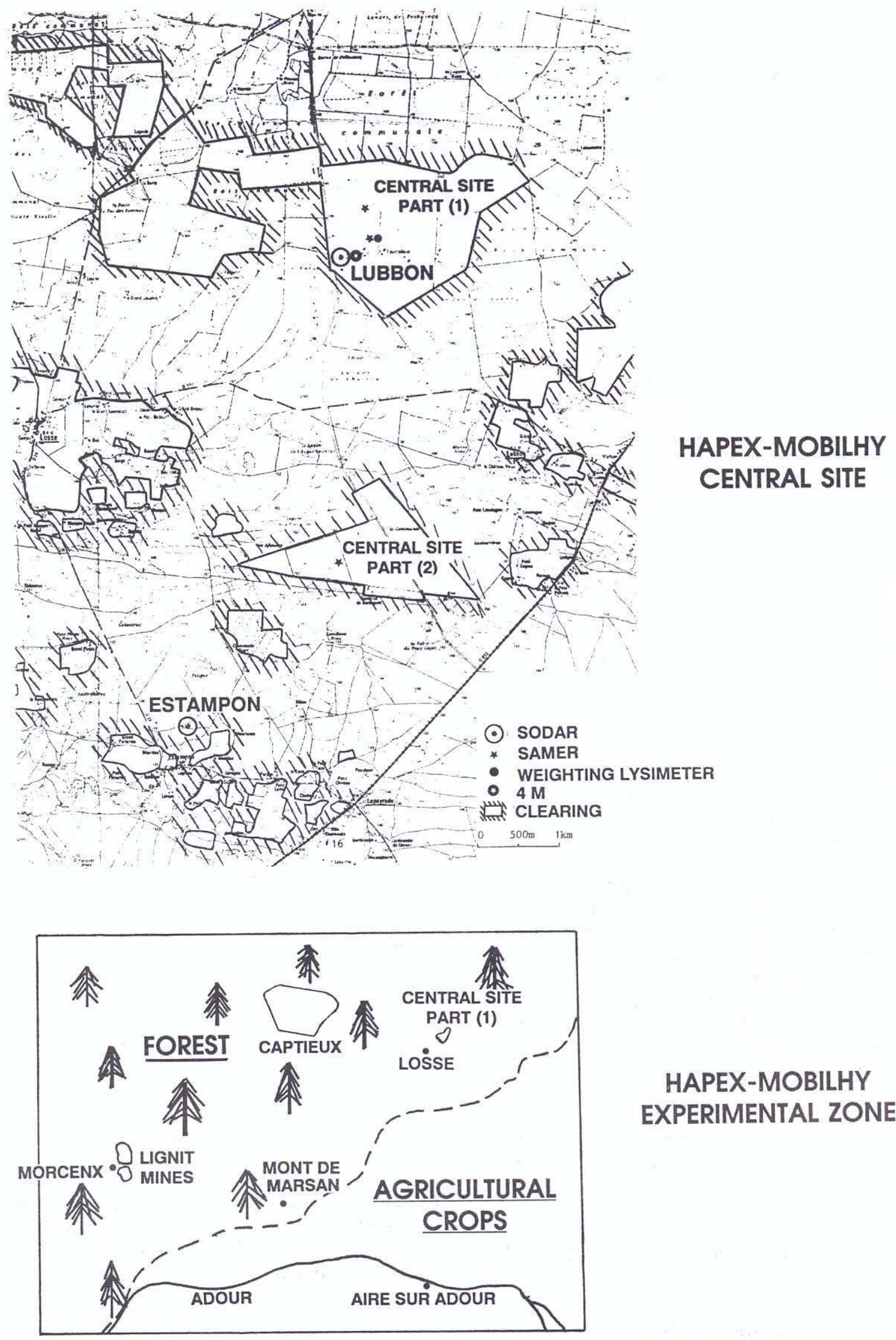

HAPEX-MOBILHY
EXPERIMENTAL ZONE

FIG. 1. Maps showing the extent of the forested area (bottom panel), and the clearings (top panel). 


\begin{tabular}{|c|c|c|}
\hline \multirow[b]{2}{*}{ Sodars } & \multicolumn{2}{|c|}{ Reflectivity and wind profiles } \\
\hline & Repetition period & Height resolution \\
\hline Sodar A & 4 seconds $(\mathrm{s})$ & $\begin{array}{l}\text { From } 19 \mathrm{~m} \text { to } 500 \mathrm{~m} \\
\text { Vertical resolution } 15 \mathrm{~m}\end{array}$ \\
\hline Sodar B & $\begin{array}{l}8 \mathrm{~s} \text { for the vertical } \\
\text { antenna } \\
16 \mathrm{~s} \text { for the others }\end{array}$ & $\begin{array}{l}\text { From } 19 \mathrm{~m} \text { to } 500 \mathrm{~m} \\
\text { Vertical resolution } 15 \mathrm{~m}\end{array}$ \\
\hline Minisodar & $1 \mathrm{~s}$ & $\begin{array}{l}\text { From } 12 \mathrm{~m} \text { to } 100 \mathrm{~m} \\
\text { Vertical resolution } 8 \mathrm{~m} \\
\text { Vertical definition } 4 \mathrm{~m}\end{array}$ \\
\hline
\end{tabular}

height. At Estampon a third sodar (minisodar) was used only during selected time periods. The CRPE sodars are monostatic Doppler systems with three antennas. Altitude profiles of two primary parameters can be derived from the doppler spectrum computed in real time for each antenna as a function of height: 1) the reflectivity of the acoustic backscattering intensity, and 2) the Doppler shift or wind component along the antenna line of sight. Table 1 details the height and time resolution of the raw data set. For more details on the sodar technique developed at CRPE, see Baudin et al. (1975, 1984) and Weill et al. (1986).

. In this paper we will compare the data from sodars $\mathrm{A}$ and $\mathrm{B}$, averaged over 15 minutes for heights equal to or higher than $34 \mathrm{~m}$. At the $19 \mathrm{~m}$ level, the forest data cannot be used. Table 2 gives the time periods

TABLE 2. Sodar data set.

\begin{tabular}{|c|c|c|c|c|}
\hline $\begin{array}{c}\text { Sodars A } \\
\text { and B } \\
T>22 \mathrm{~h}\end{array}$ & $\begin{array}{c}\text { Sodars A and B } \\
22 \mathrm{~h}\langle T\rangle 12 \mathrm{~h}\end{array}$ & $\begin{array}{c}\text { Sodars A } \\
\text { and B } \\
T<12 \mathrm{~h}\end{array}$ & $\begin{array}{c}\text { Sodar } \\
\text { A }\end{array}$ & $\begin{array}{c}\text { Sodar } \\
\text { B }\end{array}$ \\
\hline $\begin{array}{r}\text { May } 24 \\
25 \\
26 \\
28 \\
29 \\
30 \\
31 \\
\text { June } 1 \\
2 \\
3 \\
4 \\
10 \\
11 \\
15 \\
18 \\
21 \\
22 \\
23 \\
27\end{array}$ & $\begin{array}{r}\text { May } 22 \\
23 \\
27 \\
\text { June } 19 \\
20 \\
29\end{array}$ & $\begin{array}{r}\text { June } 5 \\
9 \\
12 \\
13 \\
14 \\
16 \\
17 \\
26 \\
28\end{array}$ & $\begin{array}{r}\text { June } 6 \\
7 \\
8\end{array}$ & $\begin{array}{r}\text { June } 24 \\
25 \\
30\end{array}$ \\
\hline Days: 19 & 6 & 8 & 3 & 3 \\
\hline Hours: 450 & 96 & 60 & & \\
\hline
\end{tabular}

Time of observation available for comparisons: 606 hours. during which sodar data from the intensive observational phase are available. This data set will be included in the HAPEX-MOBILHY database.

\section{Observations}

Figures 2 and 3 display the diurnal variation of the horizontal wind direction and speed observed above the two sites on 15 June 1986, at an altitude level of $34 \mathrm{~m}$. The dashed line corresponds to the unforested area Lubbon and the full line to the forested site of Estampon.

The horizontal wind direction (Fig. 2) is generally the same at the two sites during the entire day except during two periods from 0000 UTC to 0300 UTC and from 0500 UTC to 0800 UTC. We observe that the morning sector easterly wind turns westerly at 0500 UTC above the forest, and one hour later above the clearing. The wind remains easterly at both sites until the end of the day. In France a westerly wind corresponds to a wind flow from the sea to the earth.

In Fig. 3, the comparison between the horizontal wind speeds observed over the two sites at $34 \mathrm{~m}$ shows that two periods must be considered: 1) Before 1000 UTC, the magnitude of the wind is smaller than $2 \mathrm{~m}$ $\mathrm{s}^{-1}$ and very similar at the two sites; and 2) After 1000 UTC the wind speed increases over the unforested site from 2 to $5 \mathrm{~m} \mathrm{~s}^{-1}$ and then remains constant until the end of the day while the forest wind speed remains close to $2 \mathrm{~m} \mathrm{~s}^{-1}$. The $3 \mathrm{~m} \mathrm{~s}^{-1}$ difference observed between the two sites during the afternoon hours is attributed to the frictional effect of the forest. With this example we must notice that this effect depends upon the wind regime (magnitude and direction).

In Fig. 4, vertical profiles of the horizontal wind speed obtained during the convective phase are compared. The wind speed above Lubbon (dashed line) is

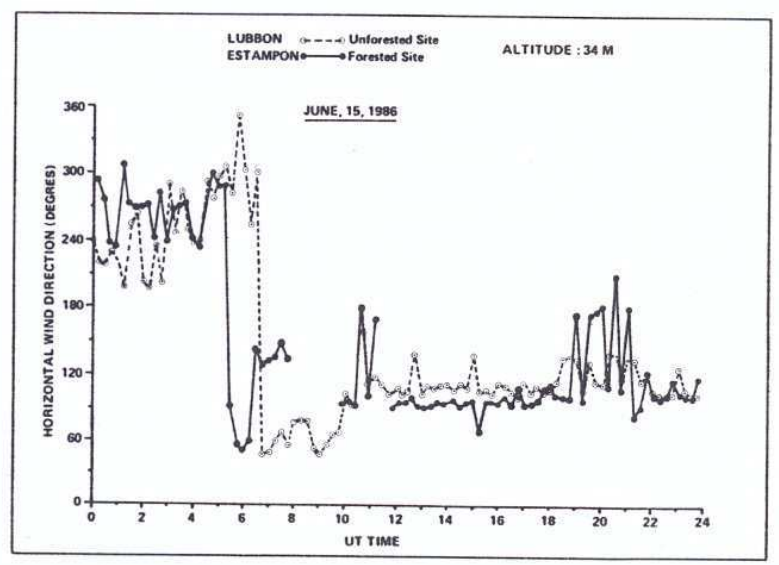

FIG. 2. The diurnal variation of the azimuth of the horizontal wind speed observed above the forested site Estampon (full line) and above the bare-ground site Lubbon (dashed line) on 15 June 1986 are superimposed. 


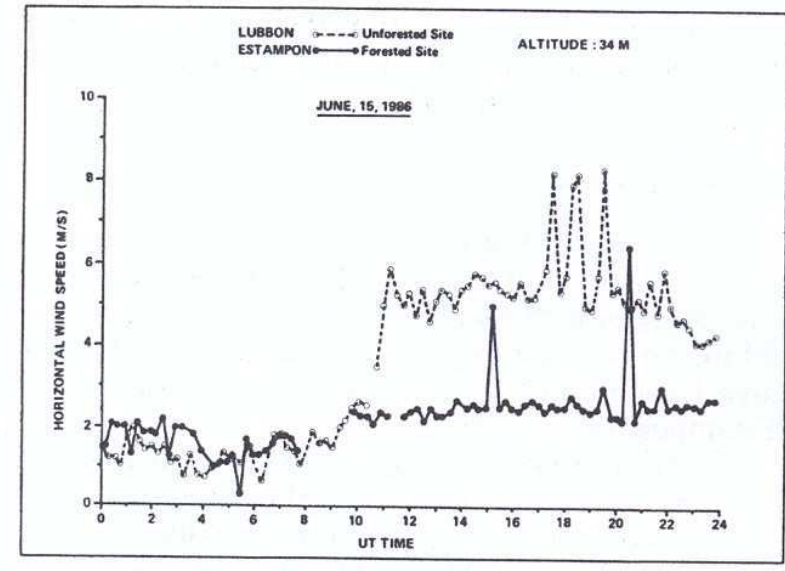

FIG. 3. Similar to Fig. 2, except that it concerns the horizontal wind speed magnitude.

nearly constant with height with a magnitude of $5.5 \mathrm{~m}$ $\mathrm{s}^{-1}$. Over the forest site (full line) two altitude ranges must be considered: 1) below $79 \mathrm{~m}$ where the wind decreases from $6.9 \mathrm{~m} \mathrm{~s}^{-1}$ to $2.5 \mathrm{~m} \mathrm{~s}^{-1}$ and 2) above $79 \mathrm{~m}$ where the wind has a constant value of $6.5 \mathrm{~m}$ $\mathrm{s}^{-1}$. The systematic difference of $1.4 \mathrm{~m}$ between the two profiles above $79 \mathrm{~m}$ is significant. Indeed the error bar is $0.5 \mathrm{~m} \mathrm{~s}^{-1}$. Hence this difference can be interpreted as due to the local wind conservation of integrated momentum. The increase of wind speed above $64 \mathrm{~m}$ over the forest balances the wind decrease below $64 \mathrm{~m}$ and is due to the forest friction effect. Such difference is not observed on 20 June 1986. Figure 5 (20 June 1986), shows that on this day the wind mag1

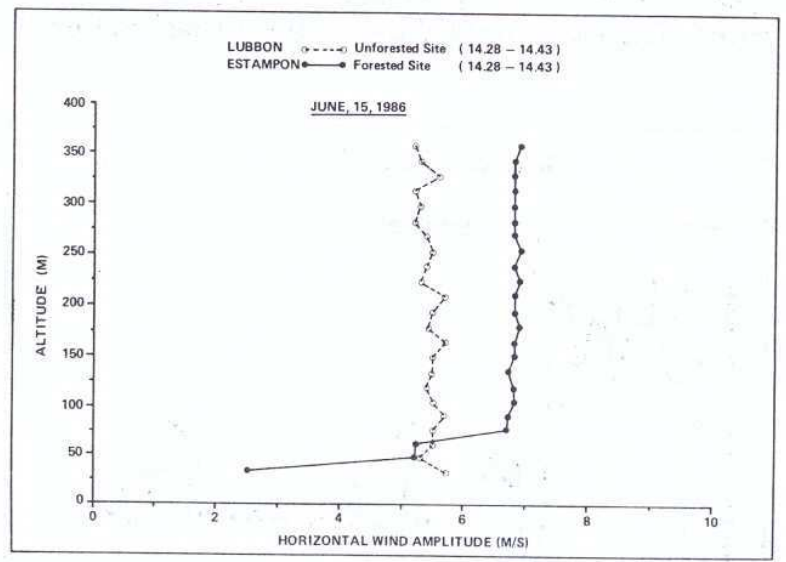

FIG. 4. Altitude profiles of the wind speed magnitude observed during a convective phase on 15 June 1986. The full fine corresponds to the wind observed above the forest, and the dashed one to the wind observed above the clearing. At altitude levels below $49 \mathrm{~m}$, one can observe a strong reduction of the wind speed magnitude above the forest. Above $64 \mathrm{~m}$ there is a systematic difference between the two wind speed magnitudes. The wind data are averaged over 15 minute intervals.

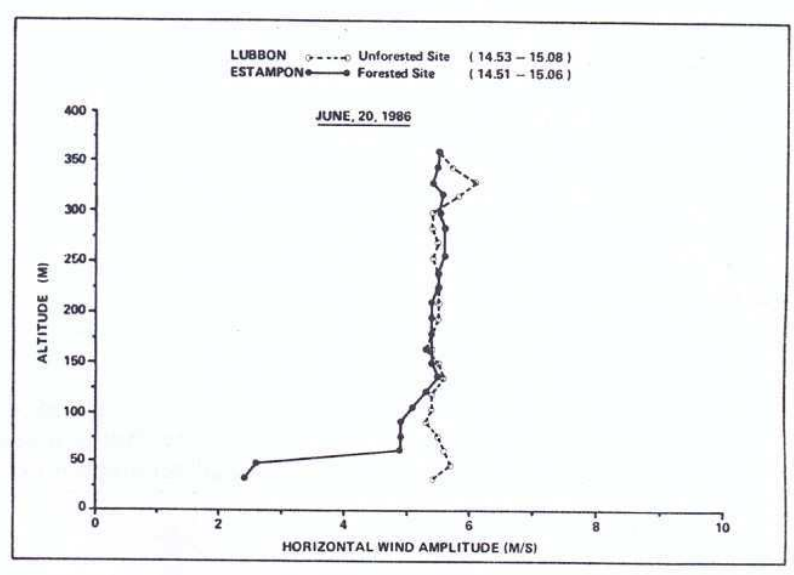

FIG. 5. Similar to Fig. 4 except that it corresponds to 20 June 1986. On this day there is no difference between the wind speed magnitude observed on the two different sites above $64 \mathrm{~m}$.

nitudes and wind shears were close to each other above $79 \mathrm{~m}$. Figure 6 shows wind speed profiles obtained during nighttime. At night the wind shear is observed within the ground based inversion layer (below 100 $\mathrm{m}$ ). Table 3 provides a quantitative comparison of the two last cases. Columns 2, 3, and 4 include, respectively, the wind speed differences between the two sites $\left(D=V^{c}-V^{f}\right)$, the wind strength above the unforested site $\left(V^{c}\right)$, and the ratio between these two quantities $\left(D / V^{c}\right)$.

From Table 3 the following relationships are suggested:

1) At altitudes equal or lower than $49 \mathrm{~m}$, the reduction of the wind varies between $30 \%$ and $60 \%$ of the wind magnitude above the clearing. Above $49 \mathrm{~m}$ the reduction is smaller, i.e., $10 \%$. This reduction is still significant at $64 \mathrm{~m}$ but not significant above this altitude.

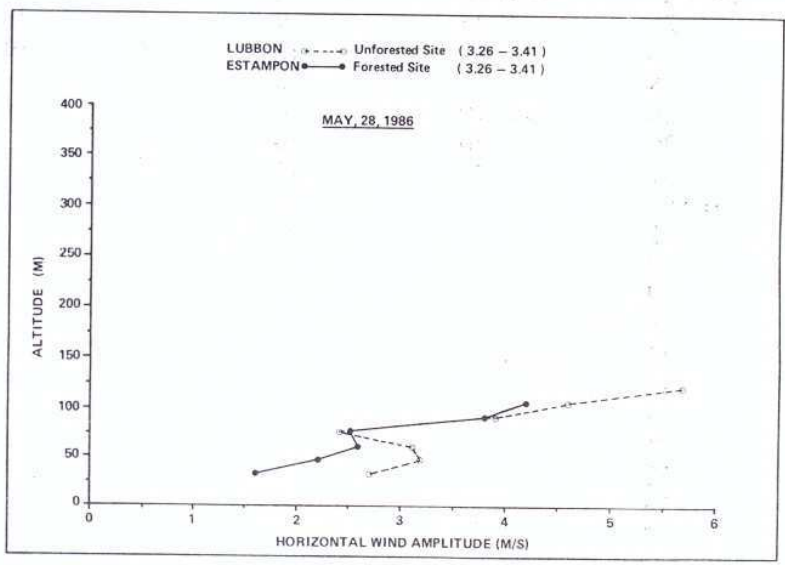

FIG. 6. Similar to Figs. 3 and 4 and corresponding to a nocturnal case. The acoustic signal is only backscattered from low altitudes, below $100 \mathrm{~m}$, where the nocturnal atmospheric turbulent layer is confined. 
TABLE 3.

\begin{tabular}{|c|c|c|c|c|c|c|}
\hline & \multicolumn{3}{|c|}{20 June 1986} & \multicolumn{3}{|c|}{28 May 1986} \\
\hline & $D=\left(V^{c}-V^{f}\right)$ & $V^{c}$ & $D / V^{c}$ & $D=\left(V^{c}-V^{f}\right)$ & $V^{c}$ & $D / V^{c}$ \\
\hline $34 \mathrm{~m}$ & 3.2 & 5.6 & $59 \%$ & 1.1 & 2.7 & $41 \%$ \\
\hline $49 \mathrm{~m}$ & 3.2 & 5.94 & $54 \%$ & 1 & 3.2 & $32 \%$ \\
\hline $64 \mathrm{~m}$ & 0.7 & 5.8 & $12 \%$ & 0.5 & 3 & $16 \%$ \\
\hline $79 \mathrm{~m}$ & 0.4 & 5.5 & $7.5 \%$ & 0 & 2.4 & $0 \%$ \\
\hline
\end{tabular}

2) The wind reduction is greater on 20 June 1986 than on 28 May 1986, in relation with the strength of the wind.

3) The altitude range where a significant wind reduction is observed is different from one day to another.

These features are related to the wind regime ( $\mathrm{mag}$ nitude and direction) and the atmospheric stability conditions.

\section{Estimation of the differential forested/unforested turbulent force}

If we assume no molecular viscous force, and horizontal homogeneity, the horizontal atmospheric motion is expressed by

$$
\frac{d}{d t}\left(\mathbf{V}_{h}\right)=f \mathbf{V}_{h} \times \mathbf{k}-\frac{1}{\rho}\left(\nabla_{h} p\right)+\frac{1}{\rho} \frac{\delta \tau}{\delta z},
$$

where $\mathbf{V}_{h}$ is the horizontal wind, $f$ the coriolis force parameter $\left(10^{-4} \mathrm{~s}^{-1}\right.$ at midlatitudes $), \rho$ the air density near the ground, $\tau$ the tangential stress acting on the horizontal surface, and $k$ the vertical unity vector (horizontal homogeneity implies that $\delta \tau / \delta x \sim \delta \tau / \delta y \sim 0$ ).

From Eq. (1), if we assume a mean steady wind and no advective terms, we can derive the following equations:

$$
\begin{aligned}
& \frac{\delta}{\delta z}\left(\tau_{x z}\right)=-\rho f\left(V-V_{g}\right) \\
& \frac{\delta}{\delta z}\left(\tau_{y z}\right)=\rho f\left(U-U_{g}\right),
\end{aligned}
$$

where $U_{g}$ and $V_{g}$ are the eastward and northward components of the geostrophic wind.

As we have two measurements of the wind obtained from two sites for which only the influence of the canopy $(\delta \tau / \delta z)$ differs, $V_{g}$ and $U_{g}$ can be assumed to be the equal at the two locations, since the distance between the two sodars is of the order of $4 \mathrm{~km}$. This assumption, verified in the present case, is not always verified in baroclinic regions.

Above the forest, for the eastward direction,

$$
\frac{\delta}{\delta z}\left(\tau_{x z}^{f}\right)=-\rho f\left(V^{f}-V_{g}\right) .
$$

Above the clearing, for the eastward direction,

$$
\frac{\delta}{\delta z}\left(\tau_{x z}^{c}\right)=-\rho f\left(V^{c}-V_{g}\right) .
$$

For the wind speed profiles shown on Figs. 5 and 6, where there is an altitude level with equal wind magnitudes, we can estimate the differential "forested/unforested" turbulent frictional stress by integrating the altitude profile of the wind speed difference between the altitudes $h^{\prime}$ and $h$.

The height $h^{\prime}$ corresponds to the low level of $34 \mathrm{~m}$, and $h$ to the level where the two wind speeds and shears are observed to be equal:

$$
\left(\tau_{x z}^{f}-\tau_{x z}^{c}\right)_{h}-\left(\tau_{x z}^{f}-\tau_{x z}^{c}\right)_{h^{\prime}}=-\rho f \int_{h^{\prime}}^{h}\left(v^{f}-v^{c}\right) d z .
$$

An estimation of this differential turbulence stress has been made for 20 June 1986, using the fact that at the level $h,\left(\tau_{x z}^{f}-\tau_{x z}^{c}\right)_{h}=0$, according to wind gradient identity

$$
\begin{aligned}
& \left(\tau_{x y}^{f}-\tau_{x y}^{c}\right)_{h^{\prime}}=-2.4810^{-4} \mathrm{~kg} \mathrm{~m}^{-1} \mathrm{~s}^{-2} \\
& \left(\tau_{y z}^{f}-\tau_{y z}^{c}\right)_{h^{\prime}}=-17610^{-4} \mathrm{~kg} \mathrm{~m}^{-1} \mathrm{~s}^{-2} .
\end{aligned}
$$

On 20 June 1986, during the afternoon hours (i.e., the period selected for the evaluation of the difference of the frictional turbulence force between the two sites), the wind is easterly.

\section{Conclusions}

This paper presents first observations of the dynamic influence of the forest on the boundary layer wind using two sodars. With such an experimental system, it has been possible to characterize the forest surface and boundary layers, and to estimate a difference of the turbulent frictional force between two sites differing by the nature of the canopy (forest and bared soil).

The sodar observations used for this paper show that 1) the forest frictional effect depends on the wind regime (magnitude and direction), 2) the transition between the forest surface layer and the forest boundary layer is sharp (we clearly observe a wind shear between 
49 and $64 \mathrm{~m}$ ), and 3 ) the difference of frictional turbulence stress is not negligible $\left(=17610^{-4} \mathrm{Kg} \mathrm{m}^{-1}\right.$ $\mathrm{s}^{-2}$ ), and the frictional effect extends to levels which are easily obtained with classical measurements.

The data shown in this paper are not representative of the whole data set. The large differences of wind magnitudes between the forested and unforested sites at the altitude level of $34 \mathrm{~m}$ are observed during convective phase, mainly on three specific days: 15 June, 20 June, and 23 June, two of which are used in this paper. On these days the wind flow is easterly during the convective period and its magnitude is large. These cases correspond to $10 \%$ of the observational daytime period. They underline the effect of an easterly wind flow on our observations, which can be explained by the location of the site (see Fig. 1).

Whatever the wind direction is, a significant wind speed difference $\left(V c-V f>1 \mathrm{~m} \mathrm{~s}^{-1}\right)$ between the two sites at the altitude level of $34 \mathrm{~m}$, is less often observed during daytime, from 0800 to 1900 UTC (20\% of time), than during the morning and evening hours $(40 \%)$. This fact can be interpreted by the atmospheric stability conditions.

Acknowledgments. The authors would like to thank all colleagues who contributed to the experiment and particularly F. Baudin, A. Sauvaget, J. Bilbille, S. Dubois, J. F. Fevre, B. Piron. The sodar studies received support grants from INSU (Institut des Sciences de l'Univers), CNET (Centre National d'études des télècommunications), CNRS (Centre National de la Recherche Scientifique).

\section{REFERENCES}

André, J. C. et al, 1988: HAPEX-MOBILHY, First results from the special observing period. submitted to Ann. Geophysi.

Baudin, F., G. Belbeoch and R. Chezlemas, 1976: Le sodar triple du CNET, Note Technique CRPE/ 28.

A. Weill, J. Bilbille, J. Fevre and B. Piron, 1984: Le minisodar Soppler du CRPE, Résultats préliminaires de sondage doppler de la couche de surface atmosphèrique. Métèorologie, 4, 35-43.

Clarke, R. H., 1970: Observational studies in the atmospheric boundary layer. Quart. J. Roy. Meteor. Soc., 96, 91-114.

Dyer, A. J., and F. J. Maher, 1965: The "Evapotron": an instrument for the measurement of eddy fluxes in the lower atmosphere. CIRSO div. Meteor. Phys. Tech. Paper $\mathrm{N}^{\circ} 15,31 \mathrm{pp}$.

_ B. B. Hicks and K. M. King, 1967: The "Fluxatron": A revised approach to the measurement of eddy fluxes in the lower atmosphere. J. Appl. Meteor., 6, 408-413.

Hicks, B. B., 1969: A simple instrument for the measurement of Reynolds stress by eddy correlation. J. Appl. Meteor., 8, 825827.

_ P. Hyson and C. J. Moore, 1975: A study of eddy fluxes over forest. J. Appl. Meteor., 14, 58-65.

Shuttleworth, J. H. et al, 1984: Eddy correlation measurements of energy partition for Amazonian forest. Quart. J. Roy. Meteor. Soc., 110, 1143-1162.

Weill, A., C. Klapisz and F. Baudin, 1986: The CRPE minisodar: applications in micrometeorology and physics of precipitation. Atmos. Res., 20, 317-333. 